\title{
食品衛生法に基づくポジティブリスト制度の導入と 動物用医薬品の対応
}

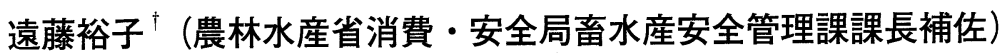

\section{1 は じめに}

「ポジティブリスト制度」は, 食品衛生法に基づき本 年 5 月 29 日に導入される食品の製造, 販売等の規制に 関する新しい制度である。この制度の下では，食品衛生 法によって畜水産物に残留する動物用医薬品がこれまで より広く規制されるので，獣医師及び動物用医薬品使用 者は，今後この新しい制度を十分理解した上で，動物用 医薬品を適切に使用いただくことが必要となる.

\section{2 ポジティブリスト制度とは}

(1) ポジティブリストとネガティブリスト

ポジティブリスト制度は，平成 15 年 5 月 30 日に公布 された「食品衛生法等の一部を改正する法律」(平成 15 年法律第 55 号）に基づき，平成 18 年 5 月 29 日に施行さ れる新しい制度であり, 食品中に残留する農薬, 動物用 医薬品及び飼料添加物（以下，「農薬等」という）を規 制するものである。この制度が導入される背景には，こ れまでの制度では，残留基準が設定されていない農薬等 が食品から検出されても, 食品衛生法による販売等の規 制ができないという状況があったことが挙げられる.

すなわち，これまで日本の食品中の農薬等の残留に関 する規制は，抗菌性物質については，「食品には抗生物 質を含有してはならない」,「食肉・食鳥卵, 魚介類は化 学的合成品たる抗菌性物質を含有してはならない」とい う規制をしているものの，これら以外の物質については 「ネガティブリスト制度」（原則規制がなく，規制するも のをリスト化する制度，この場合のリストとは残留基準 のこと）であった。これに対して，「ポジティブリスト 制度」は，原則規制（禁止）し，使用してよいものをリ スト化する制度（この場合のリストも残留基準のこと） であるので, 現状では残留基準が設定されていない農薬 等の規制ができることになる.

(2) ポジティブリスト制度の概要

このポジティブリスト制度の下では, 農薬等は, (1)残 留基準が設定されているもの，(2)制度の対象外物質（規 制されないもの), (3)残留基準が設定されていないもの, の3つのカテゴリーに分類される.この中で, 厚生労働
省告示により(1)については食品ごとに物質名と残留基準 值が示され，(2)ついては65物質が示されているが， (3)については，いずれかの食品に残留基準がある物質以 外のものについては具体的な物質名が示されていない. (3)は人の健康を損なうおそれのない量として厚生労働大 臣が定めた量（一律基準，0.01ppm）を超えて食品中に 残留してはならないとされるのだが, 食品・添加物等の 規格基準（昭和 34 年厚生労働省告示第 370 号）の一般 規則として，i）すべての食品は抗菌性物質を含有して はならない（食品添加物，一般規則に残留基準等の基準 があるものとそれらを原料として製造・加工されたもの を除く)， ii） 15 物質は食品中不検出とする， iii）食品 に自然に含まれる物質は，その食品に通常含まれる量を 超えてはならない，iv）成分規格が定められている食品 を原材料として製造または加工される食品については原 材料が成分規格に適合するものでなければならない，な どの規定があり，それらに該当するものには一律基準は 適用されない.

この制度の施行される平成 18 年 5 月 29 日には, 758

動物用医薬品は，(1)〜3)に分類される.

(1) 残留基準が設定されているもの

(2) 対象外物質として告示されたもの（65物質）

(3) 残留基準が設定されていないもの

その他に，一般規則として以下の規則等がある.

i ）食品は抗菌性物質を含有してはならない. （ただし，食品添加物，基準のあるもの，それ らを原料として加工・製造されたものを除く.)

ii）不検出物質として告示された物質がある (15物質).

iii）自然に食品に含まれる物質は，その食品に 通常含まれる量を超えてはならない.

iv）加工食品の原材料は基準に適合しなくては ならない.

図 1 ポジティブリスト制度による動物用医薬品の分類

\footnotetext{
$\dagger$ 連絡責任者：遠藤裕子（農林水産省消費 - 安全局畜水産安全管理課） 干 100-8950千代田区霞が関 1-2-1⑳3-3502-8111（内3165） FAX 03-3502-8275 
物質について残留基準が新たに設定されるが，このうち 238 物質について厚生労働省は主な用途として動物用医 薬品を挙げている. 新たに設定される残留基準は, 制度 導入までの時間が短かったため, 毒性試験成績等に基づ く食品安全委員会の通常の評価を受けておらず，暫定的 に設定されるので暫定基準と呼ばれており, 今後 5 年間 を目途に再評価が行われる予定である.

また，食品衛生法に規定する「動物用医薬品」は「薬 事法第 2 条第 1 項に規定する医薬品であって動物のため に使用することが目的とされているものの成分である物 質（その物質が化学的に変化して生成した物質を含み… …)」と記載されているので, 農林水産大臣が承認して いる専ら動物に使用される医薬品（薬事法で定める動物 用医薬品）のみに限定されず，しかも各物質の代謝物も 含むと考えられる.いずれも平成 17 年 11 月 29 日に公 布された厚生労働省告示第 497 号（一律基準值を $0.01 \mathrm{ppm}$ と定めるもの)，第 498 号（対象外物質として 65 物質を定めるもの)，第 499 号（暫定基準，不検出物 質, 自然に含まれる物質等の取り扱いについて定めるも の）に示されている. 関連の告示, 通知等の詳細につい ては厚生労働省のホームページ（http://www.mhlw. go.jp/topics/bukyoku/iyaku/syoku-anzen/zanryu2/ index.html）をご覧いただきたい.

（3）残留モニタリングと試験法

ポジティブリスト制度においては, 不検出物質及び残 留基準のある物質については, 高感度の残留分析法が厚 生労働省により示されている（試験法も上記の厚生労働 省ホームページからダウンロードできる). 高速液体ク ロマトグラフ法による多成分一斉分析法も示されてお り，この方法によれば 1 検体から同時に多数の残留情報 が得られる. したがって, 厚生労働省の実施している残 留モニタリングによる違法残留の検出率も大幅に向上す ることが予想される。しかし，まだ残留基準のあるすべ ての物質についての残留分析法が示されている訳ではな く，また国産の畜産物のモニタリングを実施している各 都道府県の機器の整備状況なども異なることから, 都道 府県においてこれらの方法が全て実施されるまでにまだ 時間がかかると思われる。

\section{3 薬事法の規制とポジティブリスト制度への対応}

ポジティブリスト制度に対応するために，農林水産省 は,「投与後, 定められた休薬期間経過後に生産される 畜水産物が食品衛生法による規制に適合する.」よう対 策を行っている.つまり, 農林水産大臣が製造販売承認 している動物用医薬品について, 薬事法の規定に基づい て動物用医薬品の使用の規制に関する農林水産省令（昭 和 55 年農林水産省令第 42 号）により定めている使用基 準及び個々の動物用医薬品について承認している休薬期

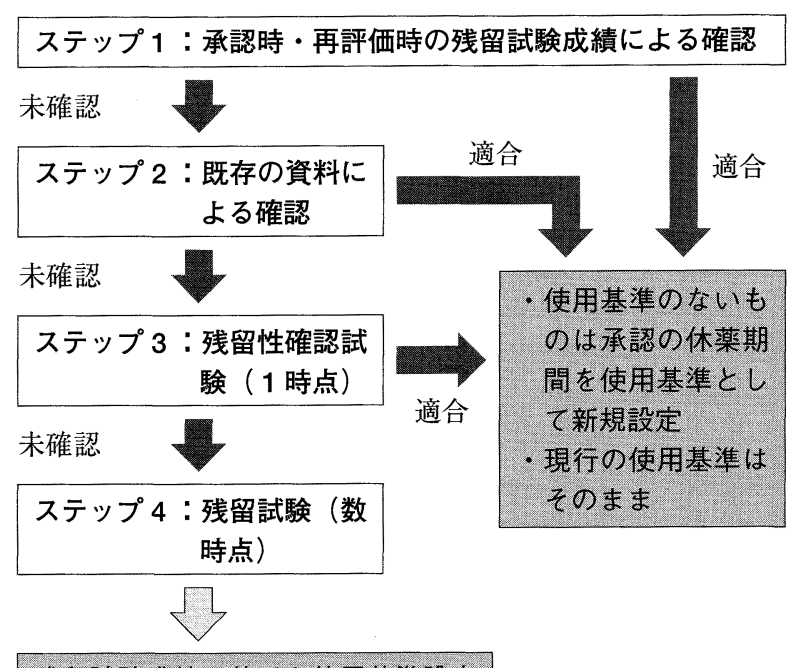

残留試験成績に基つうき使用基準設定

図2 残留基準が設定されるものについての作業

間をポジティブリスト制度に適合するように改正または 変更し, 食品衛生法による新しい規格基準に適合する畜 水産物が生産されるよう規制していくこととしている. なお, 使用基準を設ける医薬品においては「使用禁止期 間」, 使用基準のない医薬品の承認においては「休薬期 間」という表現をしているが，意味するところは同じ で，食用に供するためにと殺，搾乳，採卵，はちみつ等 の採取をする前に医薬品を投与してはならない期間であ る.

具体的には, 現在製造販売承認されている動物用医薬 品の使用基準及び休薬期間が食品衛生法の新しい規格基 準に適合しているかどうかについて，これらの承認申請 の際の対象動物を用いた残留試験資料, 再評価の際の残 留試験に関する資料を用いて確認する（ステップ1）, 学 術文献等を用いて確認する（ステップ2）, 農林水産省が 新たに残留試験を実施して確認する（ステップ 3, 承認 された休薬期間経過後の 1 時点で採材し分析する試験） 及びさらに残留試験を実施して新しい使用基準または休 薬期間を設定する（ステップ 4, 医薬品投与後数時点で 採材し分析する試験）の 4 段階の作業を実施し, 必要が あれば現行の使用基準の使用禁止期間または承認の休薬 期間を延長して対応する。ただし，ポジティブリスト制 度の導入までの限られた時間と予算を有効に活用するた め, 現行の使用基準がある動物用医薬品と残留基準（暫 定基準）が新たに設定される動物用医薬品について優先 的に作業を進めた．なお，これらの対応方針，検討内容 及び施策への反映（使用基準の改正，承認の休薬期間の 変更等)については薬事・食品衛生審議会の意見を聴い て決定している．この作業のフローチャートを図 2 に示 した. 
表 1 使用基準の改正によって使用禁止期間が延長される医薬品

\begin{tabular}{|c|c|c|c|}
\hline 医 薬 品 & 使用対象動物 & 使用禁止期間（改正前） & 使用禁止期間（改正案） \\
\hline $\begin{array}{l}\text { 硫酸ジヒドロストレプトマイシンを } \\
\text { 有効成分とする注射剤（使用基準の } \\
\text { 別表第 } 2 \text { に掲げるものを除く.) }\end{array}$ & 馬 & $\begin{array}{l}\text { 食用に供するためにと殺する前 } \\
\text { 30日間 }\end{array}$ & $\begin{array}{l}\text { 食用に供するためにと殺する前 } \\
60 \text { 日間 }\end{array}$ \\
\hline \multirow[t]{2}{*}{$\begin{array}{l}\text { スルファモノメトキシンを有効成分 } \\
\text { とする注射剤 }\end{array}$} & 牛 & $\begin{array}{l}\text { 食用に供するためにと殺する前 } \\
7 \text { 日間または食用に供するため } \\
\text { に搾乳する前 } 72 \text { 時間 }\end{array}$ & $\begin{array}{l}\text { 食用に供するためにと殺する前 } \\
\text { 28日間または食用に供するため } \\
\text { に搾乳する前72時間 }\end{array}$ \\
\hline & 豚 & $\begin{array}{l}\text { 食用に供するためにと殺する前 } \\
7 \text { 日間 }\end{array}$ & $\begin{array}{l}\text { 食用に供するためにと殺する前 } \\
\text { 14日間 }\end{array}$ \\
\hline
\end{tabular}

(注意) 改正案は修正される可能性がある.

（1）使用基準による対応

使用基準については，(1)現在動物用医薬品として製造 販売承認がない医薬品の基準を削除する，(2)新たに使用 基準を追加する，(3)現在の使用基準の内容を変更する， の3つの内容を含む改正をポジティブリスト制度の施行 と同時に実施する（農林水産省令改正施行日は平成 18 年 5 月 29 日).

また，従来使用基準は抗菌性物質と残留基準のある内 部/外部寄生虫駆除薬について設定してきたが，ポジテ イブリスト制度の下ではこれら以外の薬効分類の動物用 医薬品についても残留基準が設定されるため, 今回の改 正以降はさまざまな効能・効果の医薬品についても使用 基準に収載されることになる，最近の改正案の内容につ いては, 農林水産省動物医薬品検査所のホームページ (http://www.nval.go.jp) でご覧いただきたい.

\section{（2）休薬期間による対応}

暫定基準が設定される動物用医薬品には，一部の対象 動物についての使用禁止期間の決定のための試験資料が 十分でなかった等の理由でポジティブリスト制度の施行 と同時の使用基準設定ができなかったものがある.ま た，暫定基準が設定されなかった動物用医薬品のうち， 使用方法等から畜水産物に残留する可能性があると推定 されるものについては, 残留試験成績, 吸収・排泄・体 内分布等の試験成績, 物理化学的性質, 他の対象動物の 試験成績, 類似の性質の動物用医薬品の試験成績を広く 総合的に考察し，休薬期間の設定または承認された休薬 期間の変更をする．これらの場合には個々の動物用医薬 品ごとの対応となるので, 個々の製品に変更を記載した 説明書を添付するなど獣医師及び使用者に対する情報提 供に努めていきたい. 不明な場合には当該製剤の製造販 売業者に問い合わせいただくか，農林水産省動物用医薬 品検査所のホームページでご覧いただきたい.

\section{4 農林水産省の今後の対応}

（1）厚生労働省による暫定基準の見直し

残留基準は，本来その物質の毒性試験成績から得られ た無影響量を安全係数で除して算出される 1 日摂取許容
量（ADI）と残留試験成績等に基づいて算出されるもの であるが，今回設定された暫定基準はそのような評価方 法によって設定されたものではなく, 動物用医薬品につ いては承認申請時の残留試験の検出限界值や各国の残留 基準值を根拠として, 食品安全委員会による通常の評価 を受けずに，暫定的に設定された值であるので，厚生労 働省はポジティブリスト制度の施行後 5 年間を目途と し, 食品安全委員会による暫定基準值の評価を受けて, 必要な修正を行っていく予定としている.

（2）今後の使用基準の改正, 休薬期間の変更

農林水産省は, 厚生労働省の暫定基準值の見直しの結 果に対応した使用基準の改正や休薬期間の変更を行って いく予定である。また，ポジティブリスト制度の施行ま でに使用基準が設定されなかった動物用医薬品や新たに 実施された残留試験成績等により休薬期間の延長が必要 であると判明した動物用医薬品については, 今後も引き 続き使用基準の設定, 休薬期間の变更を行っていく予定 である。

\section{5 診療獣医師の方々へのお願い}

食品衛生法違反を未然に防止するために，診療獣医師 の方々に以下の対応をお願いしたいと考えている．特 に，使用基準改正とポジティブリスト制度の施行日が同 じ日（5月 29 日）であるので，改正により使用禁止期間 の延長が行われる医薬品については, 改正前の使用時に は使用禁止期間を遵守して使用したにもかかわらず，施 行日を過ぎて食品となった時にはその時点の残留基準值 を超えて残留してしまう場合もあるので，このような医 薬品を施行日間近に使用する場合には，十分注意してい ただきたい。たとえば，使用禁止期間が 7 日の医薬品の 使用禁止期間が 14 日に延長され，これを 5 月 20 日に使 用した家畜を 5 月 30 日にと殺する場合には，使用時点 の薬事法の規制には適合しているが，ポジティブリスト 制度の下での新しい残留基準値を超えてしまい, 食品衛 生法には適合しない畜産物が生産される可能性があるこ とになる。

（1）最新の使用基準及び休薬期間を正確に把握し，遵 
表 2 使用基準の改正によって承認された休薬期間より長い使用禁止期間が設定される医薬品

\begin{tabular}{|c|c|c|c|}
\hline 医 薬 品 & 使用対象動物 & "使用禁止期間（改正前） & "使用禁止期間（改正案） \\
\hline $\begin{array}{l}\text { カルバリルを有効成分とする外皮散 } \\
\text { 布剤 }\end{array}$ & $\begin{array}{c}\text { 牛 } \\
(\text { (搾乳牛を除く) } \\
\text { 鷄 }\end{array}$ & $\begin{array}{l}\text { 食用に供するためにと殺する前 } \\
2 \text { 日間 } \\
\text { 食用に供するためにと殺する前 } \\
2 \text { 日間 }\end{array}$ & $\begin{array}{l}\text { 食用に供するためにと殺する前 } \\
7 \text { 日間 } \\
\text { 食用に供するためにと殺する前 } \\
7 \text { 日間または食用に供する卵の } \\
\text { 産卵前 } 1 \text { 日間 }\end{array}$ \\
\hline $\begin{array}{l}\text { カルバリルを有効成分とする外皮噴 } \\
\text { 霧剂 }\end{array}$ & $\begin{array}{c}\text { 牛 } \\
\text { (搾乳牛を除く) } \\
\text { 鷄 }\end{array}$ & $\begin{array}{l}\text { 食用に供するためにと殺する前 } \\
2 \text { 日間 } \\
\text { 食用に供するためにと殺する前 } \\
2 \text { 日間 }\end{array}$ & $\begin{array}{l}\text { 食用に供するためにと殺する前 } \\
7 \text { 日間 } \\
\text { 食用に供するためにと殺する前 } \\
7 \text { 日間または食用に供する卵の } \\
\text { 産卵前 } 1 \text { 日間 }\end{array}$ \\
\hline $\begin{array}{l}\text { ナフシリンナトリウムモノハイドレ } \\
\text { ートを有効成分とする乳房注入剤 }\end{array}$ & $\begin{array}{l}\text { 牛 } \\
\text { (泌乳している } \\
\text { ものに限る) }\end{array}$ & $\begin{array}{l}\text { 食用に供するためにと殺する前 } \\
7 \text { 日間または食用に供するため } \\
\text { に搾乳する前 } 72 \text { 時間 }\end{array}$ & $\begin{array}{l}\text { 食用に供するためにと殺する前 } \\
\text { 14日間または食用に供するため } \\
\text { に搾乳する前132時間 }\end{array}$ \\
\hline $\begin{array}{l}\text { ビチオノールを有効成分とする強制 } \\
\text { 経口投与剤 }\end{array}$ & 馬 & $\begin{array}{l}\text { 食用に供するためにと殺する前 } \\
\text { 10日間 }\end{array}$ & $\begin{array}{l}\text { 食用に供するためにと殺する前 } \\
\text { 15日間 }\end{array}$ \\
\hline $\begin{array}{l}\text { メンブトンを有効成分とする強制経 } \\
\text { 口投与剤 }\end{array}$ & $\begin{array}{l}\text { 豚（生後 } 4 \text { 月を } \\
\text { 越えるものを } \\
\text { 除く） }\end{array}$ & $\begin{array}{l}\text { 食用に供するためにと殺する前 } \\
3 \text { 日間 }\end{array}$ & $\begin{array}{l}\text { 食用に供するためにと殺する前 } \\
5 \text { 日間 }\end{array}$ \\
\hline メンブトンを有効成分とする注射剂 & \begin{tabular}{l}
\multicolumn{1}{c}{ 牛 } \\
(泌乳している \\
ものに限る)
\end{tabular} & $\begin{array}{l}\text { 食用に供するためにと殺する前 } \\
6 \text { 日間または食用に供するため } \\
\text { に搾乳する前 } 72 \text { 時間 }\end{array}$ & $\begin{array}{l}\text { 食用に供するためにと殺する前 } \\
25 \text { 日間または食用に供するため } \\
\text { に搾乳する前72時間 }\end{array}$ \\
\hline $\begin{array}{l}\text { 硫酸カナマイシン及びベンジルペニ } \\
\text { シリンプロカインを有効成分とする } \\
\text { 配合剤たる乳房注入㓱 }\end{array}$ & $\begin{array}{l}\text { 牛 } \\
\text { (泌乳している } \\
\text { ものに限る) }\end{array}$ & $\begin{array}{l}\text { 食用に供するためにと殺する前 } \\
7 \text { 日間または食用に供するため } \\
\text { に搾乳する前96時間 }\end{array}$ & $\begin{array}{l}\text { 食用に供するためにと殺する前 } \\
50 \text { 日間または食用に供するため } \\
\text { に搾乳する前96時間 }\end{array}$ \\
\hline $\begin{array}{l}\text { 硫酸ジヒドロストレプトマイシン及 } \\
\text { びベンジルペニシリンプロカインを } \\
\text { 有効成分とする配合剤たる乳房注入 } \\
\text { 骩 }\end{array}$ & $\begin{array}{l}\text { 牛 } \\
\text { (泌乳している } \\
\text { ものに限る) }\end{array}$ & $\begin{array}{l}\text { 食用に供するためにと殺する前 } \\
7 \text { 日間または食用に供するため } \\
\text { に搾乳する前96時間 }\end{array}$ & $\begin{array}{l}\text { 食用に供するためにと殺する前 } \\
11 日 \text { 間または食用に供するため } \\
\text { に㵠乳する前96時間 }\end{array}$ \\
\hline
\end{tabular}

（注意）改正案は修正される可能性がある.

守すること.

○使用基準の改正によって使用禁止期間が延長される 医薬品がある (表 1 参照).

○使用基準に新たに収載される医薬品には，従来の承 認の休薬期間より長い使用禁止期間となるものがあ る (表 2 参照).

○使用基準に収載されていない医薬品の中にも，従来 の承認の休薬期間より長い休薬期間となるものがあ る. 本稿作成段階ではまだ示すことができないが, 本誌発行時には確定しているので，製造販売会社に お問い合わせいただくか，農林水産省動物医薬品検 査所のホームページでご覧いただきたい.

○後も使用基準の改正，休薬期間の変更があるの で引引き続き注意いただきたい。

（2）動物用医薬品の承認されている用法・用量以外の 使用方法を避けること.もし, 承認と異なる対象動物, 承認と異なる投与経路，承認より多い用量で使用する場 合には，安全のために休薬期間を十分に長くとること.

○対象動物により残留基準值が異なる場合がある。
○対象動物により，吸収，分布，排泄が異なる場合が ある。

（3）人体用医薬品を食用動物に使用する場合には，残 留基準值の有無を確認の上, 類似の化学構造の動物用医 薬品を参考にするなどして使用すること.

○人体用医薬品には残留基準が設定されていないもの が多くある。

（4）個人輸入により購入した国内承認のない動物用医 薬品を食用動物に使用する場合には，輸入元の残留基準 と日本の残留基準の相違を確認し，異なる場合には添付 文書の休薬期間を遵守しても日本の残留基準に適合しな い場合があることを考慮し，十分な休薬期間を適用する こと.

○外国の残留基準値と日本の残留基準值には大きいも のでは約 100 倍もの差がある.

（5）農家にポジティブリスト制度について理解を促 し，動物用医薬品の使用について適切な指示をし，休薬 期間の遵守を指導するとともに，使用の記録を付けるよ う指導すること。 
○使用の記録については，農林水産省動物医薬品検査 所のホームページに簡単な説明があるので，参考と されたい.

6 終わりに

以上，農薬等のポジティブリスト制度と動物用医薬品
に関する農林水産省のその対応について述べた。この制 度について, 臨床獣医師の皆様が理解され, 適切に刘応 されるよう協力いただきたい。今後もいろいろな媒体を 用いて制度について引き続き扮知らせしたい。

\section{紹 介}

\section{平成 17 年度日本獣医師会獣医学術奨励賞受賞 研究業績及び受賞者の紹介}

本年度の日本獣医師会獣医学術奨励賞選考は, 学術賞 は日獣会誌の平成 15 年 8 月号（第 56 巻第 8 号）から平 成 17 年 7 月号（第 58 巻第 7 号）に揭載された原著・短 報を対象に，奨励賞は学会年次大会（つくば）において 発表された地区学会長賞の中から選考された学会長賞 に，功労賞は推薦のあった永年の功労の業績の中から， 選考委員会において厳正に審査され，受賞者には平成 17 年度日本獣医師会三学会年次大会（つくば）会期中 に開催された授与式において本会山根会長から本賞及 び，協賛会社（共立製薬(株)，日本全薬工業(侏)，日本八厶 株）からの研究奨励金20万円（目録）が授与された。

表彰された研究業績ならびに受賞者を以下に紹介する.

\section{[小動物部門]}

学術賞：「高歯大の重度歯周病に対する治療ならびに歯 周病関連細菌の分離」(日本獣医師会雑誌第 57 巻第 1 号)

湯本哲夫，他（湯本ペットクリニック・埼玉県）

奨励賞：「子宮頸隓部の受精機能を利用し，子宮体内一 精液注入を行った犬の経腔人工授精法」

川又 哲，他（川又犬猫病院・北海道）

功労賞：「獣医麻酔外科学, 特に小動物麻酔学の研究・ 発展とその普及」鈴木立雄

\section{〔産業動物部門〕}

学術賞：「牛腎由来株化細胞 MDBK-SYを用いた牛ウイ ルス性下痢ウイルス持続感染牛の簡易検査法」 (日本獣医師会雑誌第 57 巻第 12 号) 齋藤俊哉（栃木県県央家畜保健衛生所）

奨励賞：「初乳の加温処理による病原体の不活化と子牛 への給与試験並びに加温処理器の検討」 中岡祐司，他（北海道石狩家畜保健衛生所）
功労賞：「SPF豚による疾病清浄化技術の開発と普及」 柏崎 守

\section{〔公衆衛生部門〕}

学術賞：「山口県内の飼猫からのバルトネラ属菌の分離 と分離株の分子疫学的解析」（日本獣医師会雑 誌第 57 巻第 10 号)

冨田正章，他（山口県環境保健研究センター）

奨励賞：「ブタ盲腸便からのC群ロタウイルス検出とそ の遺伝子解析」

暮谷光隆，他（岡山県環境保健センター）

功労賞：「食中毒等の各種統計解析処理の発展とその普 及」務中昌已

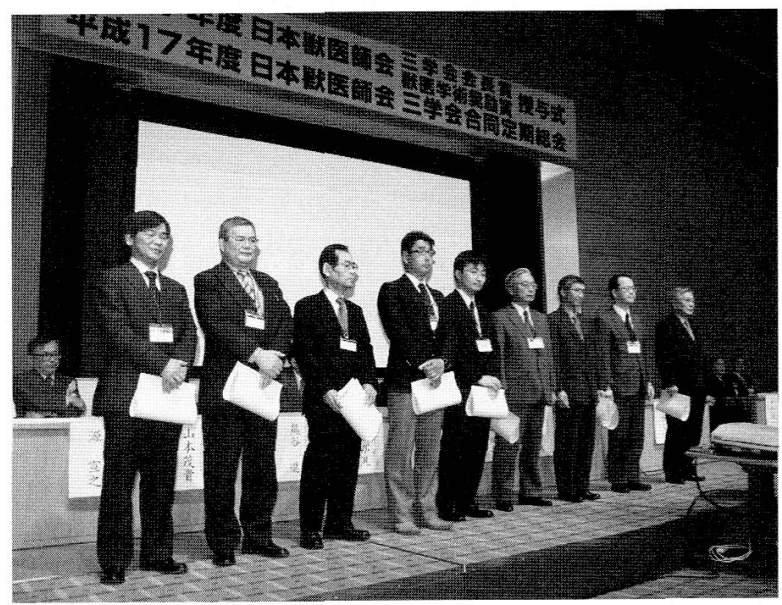

平成 17 年度日本獣医師会獣医学術奨励賞の受賞者（左 から，湯本哲夫，川又 哲，鈴木立雄，齋藤俊哉，中岡 祐司 (代理), 柏崎 守, 冨田正章, 暮谷光隆, 務中昌己 の各氏） 